Plant and Soil 162: 135-146, 1994.

(C) 1994 Kluwer Academic Publishers. Printed in the Netherlands

\title{
Fine root growth phenology, production, and turnover in a northern hardwood forest ecosystem
}

\author{
Marianne K. Burke' and Dudley J. Raynal \\ State University of New York, College of Environmental Science and Forestry Syracuse, NY 13210, USA. 'Present \\ address: Southeastern Forest Experiment Station, USDA Forest Service, Charleston, SC 29414, USA
}

Received 30 August 1993. Accepted in revised form 24 January 1994

Key words: fine roots, northern hardwood forest, nutrient cycling, phenology, production, turnover

\begin{abstract}
A large part of the nutrient flux in deciduous forests is through fine root turnover, yet this process is seldom measured. As part of a nutrient cycling study, fine root dynamics were studied for two years at Huntington Forest in the Adirondack Mountain region of New York, USA. Root growth phenology was characterized using field rhizotrons, three methods were used to estimate fine root production, two methods were used to estimate fine root mortality, and decomposition was estimated using the buried bag technique. During both 1986 and 1987, fine root elongation began in early April, peaked during July and August, and nearly ceased by mid-October. Mean fine root $\left(\leqslant 3 \mathrm{~mm}\right.$ diameter) biomass in the surface $28-\mathrm{cm}$ was $2.5 \mathrm{t} \mathrm{ha}^{-1}$ and necromass was $2.9 \mathrm{t}$ ha- $`$. Annual decomposition rates ranged from 17 to $30 \%$ beneath the litter and 27 to $52 \%$ at a depth of $10 \mathrm{~cm}$. Depending on the method used for estimation, fine root production ranged from 2.0 to $2.9 \mathrm{tha}^{-1}$, mortality ranged from 1.8 to $3.7 \mathrm{t}$ $\mathrm{ha}^{-1} \mathrm{yr}^{-1}$, and decomposition was $0.9 \mathrm{tha}^{-1} \mathrm{yr}^{-1}$. Thus, turnover ranged from 0.8 to $1.2 \mathrm{yr}^{-1}$. The nutrients that cycled through fine roots annually were 4.5-6.1 kg Ca, 1.1-1.4 kg Mg, 0.3-0.4 kg K, 1.2-1.7 kg P, 20.3-27.3 kg $\mathrm{N}$, and 1.8-2.4 $\mathrm{kg} \mathrm{S} \mathrm{ha}^{-1}$. Fine root turnover was less important than leaf litterfall in the cycling of $\mathrm{Ca}$ and $\mathrm{Mg}$ and was similar to leaf litterfall in the amount of N, P, K and S cycled.
\end{abstract}

\section{Introduction}

Although the importance of roots in net primary production and forest biogeochemical cycling is acknowledged (Aber et al., 1991; Cox et al., 1978; Johnson and Lindberg, 1992; Joslin and Henderson, 1987; Raich and Nadelhoffer, 1989), a lack of reliable information on root production and turnover has limited nutrient cycling studies in temperate deciduous forests (Hendrick and Pregitzer, 1993; Nadelhoffer and Raich, 1992; Vogt and Bloomfield, 1991). When root production, mortality and decomposition are not considered, the turnover of organic matter and nutrients may be underestimated by 20 to $80 \%$ (Vogt et al., $1986 \mathrm{~b}$ ), so the direct measurement of fine root production and turnover remains important in the development of accurate ecosystem nutrient budgets.

Fine root dynamics are seldom measured directly because these studies are labor intensive. Also, meth- ods are not standardized (Lauenroth et al., 1986; Nadelhoffer and Raich, 1992; Singh et al., 1984; Vogt et al., 1986a; Vogt and Persson, 1990). Consequently,, substantially different estimates can result when different methods are used. For example, McClaugherty et al. (1982) calculated very different fine root production estimates when they compared two methods commonly in use at the time. Concern about the random error associated with the minimum minus maximum method, and the potential for the overestimation associated with methods based on sequential sampling (Kurz and Kimmins, 1987; Lauenroth et al., 1986; Persson, 1980b; Singh et al., 1984) stimulated root biologists to propose improved sampling protocols for estimating fine root production. One protocol employed site-specific vegetation phenology to approximate the times of biomass maxima and minima, and also used statistical procedures to identify 'real' changes in mass. This phenology-based method, 
proposed by Vogt et al. (1986a), calculated production as significant increments in biomass plus significant increments in necromass plus decomposition. Mortality was calculated as the significant increments in necromass plus decomposition. Estimates produced using this method have not been compared with estimates derived using other methods for any forested ecosystem. The first objective of this study was to compare and evaluate estimates obtained using the phenologybased method with two other methods, the maximum minus minimum method (Aber et al., 1985; Edwards and Harris, 1977, McClaugherty et al., 1982) and an equation developed by Nadelhoffer and Raich (1992) using a relationship between aboveground litterfall and fine root production based on a N-budget method.

Because the phenology-based method required an accurate assessment of the phenology of root growth, the second objective of this study was to document the timing of fine root production in situ. This was necessary because published reports of peak fine root production varied for temperate deciduous forests. Spring was the period of peak production in some reports (Harley, 1937; Joslin and Henderson, 1987; Morrow, 1950), however, McClaugherty et al. (1982) reported a spring peak in production but an autumn maximum in fine root biomass. Spring and fall peaks in biomass production were reported in other studies but that pattern was attributed to a mid-season cessation of root production caused by dry soil conditions (Harris et al., 1977; Teskey and Hinkley, 1981). We assumed that fine root elongation was proportional to fine root production, and that if fine root production was unimodal, peak fine root biomass would occur just after elongation declined.

The third objective of the study was to estimate the contribution of fine roots to organic matter and nutrient budgets in this northern hardwood forest. Because three different methods were employed to estimate fine root production, and two methods were used to calculate mortality, a range of flux values was calculated.

\section{$M$ aterials and methods}

\section{Study area}

The study site was located near Arbutus Lake at the Huntington Wildlife Forest, Newcomb, Essex County, New York, USA (latitude 44" 00”, longitude 74“" $13 ")$, in the Adirondack State Park. Elevation of the study site is $530 \mathrm{~m}$, and the total annual precipita- tion averages $106 \mathrm{~cm}$. The climate is moist, cool and continental, with mean air temperature of $-8.7^{\circ} \mathrm{C}$ in January and $18.8^{\circ} \mathrm{C}$ in July (Raynal et al., 1983). Typical of much of the Adirondack region, the forest at the site was cut heavily about 80 years ago and a northern hardwood forest has naturally regenerated. The site is dominated by sugar maple (Acer saccharum Marsh.), American beech (Fagus grandifolia Ehrh.), yellow birch (Betula alleghaniensis Britton), and red maple (Acer rubrum L.). The soil is a Typic Haplorthod: a Becket bouldery fine sandy loam (Mollitor and Raynal, 1982; Somers, 1986). Both rock and organic matter content are high (David et al., 1987), with coarse fragment content measuring $4.6 \%$ in the $\mathrm{O} / \mathrm{A}, 18 \%$ in the $\mathrm{E}, 15.4 \%$ in the $\mathrm{B}_{\mathrm{h}}, 18.8 \%$ in the $\mathrm{B}_{\mathrm{hs}}$, and $28.4 \%$ in the $\mathrm{B}_{\mathrm{s}}$ horizons.

\section{Field methods}

The phenelogy of fine root elongation was determined using root observation chambers (Keyes and Grier, 1981). Six chambers (rhizotrons) were installed during the summer of 1985 at sites chosen to encompass the topographic variation of the site. Rhizotrons were framed on three sides using pine lumber; the fourth side was a 6-mm thick pane of glass $61 \mathrm{~cm}$ deep and $91 \mathrm{~cm}$ wide. The glass was installed 2 to $6 \mathrm{~cm}$ in front of and level with the surface of the soil profile and the profile was reconstructed behind the glass using soil excavated from the rhizotron pit. Initial bulk densities were approximated in the reconstituted profile by packing soil after each layer addition.

To maintain darkness and natural soil temperature conditions, each rhizotron was fitted with a wooden lid lined with $5 \mathrm{~cm}$ of Styrofoam insulation (DOW board). A removable piece of insulation was fitted snugly against the glass face, and insulation was glued to the inside of the wooden frame. Foot traffic was excluded from the area behind the glass face to prevent soil compaction and disturbance.

Root elongation was measured for two calendar years beginning six months after rhizotron construction (December 1985). Root length increments were recorded at approximately 10 day intervals in the growing season and monthly in the winter by tracing growth increments onto transparent acetate sheets that were placed over the glass face and illuminated with a portable fluorescent lamp. The blank acetate sheet was placed over an acetate sheet on which the previously accumulated growth increments had been traced. After each tracing of new roots, the incremental growth 
was measured and then traced onto the baseline sheet. This method entailed careful matching of the baseline sheet with references on the glass faces. There was no distinction made between the diameter size classes or species of roots measured, and root mortality was not measured.

The phenological status of the canopy was also documented each time the rhizotrons were visited. The timing of bud swell, bud burst, flowering, leaf expansion, foliage coloring and foliage loss was noted.

Soil temperature was measured using YSI series 400 probes at 10 and $50 \mathrm{~cm}$ depths behind the glass of each of the six rhizotrons and in two adjacent control sites. Soil moisture was monitored at the same depths $1 \mathrm{~m}$ behind each glass face using tensiometers (Soilmoisture Equipment Corp.) from mid-May to September during both years.

A pilot study was conducted in the autumn of 1985 to determine the number of biomass samples that were needed to obtain precision of $\pm 20 \%$ standard error of the mean, which is the range about the mean where two-thirds of the values would fall. During both the pilot and post-pilot studies, soil cores $10 \mathrm{~cm}$ in diameter and up to $28 \mathrm{~cm}$ in depth were collected using a method employed by Joslin and Henderson (1987): a thinwall, hollow cylindrical steel bit with a diamond saw blade (Soiltest) was mounted on a portable, gasoline powered, dual operator post-hole digger (Tecumseh, General-3 1) via an adapter (Soiltest) and a machined shaft. Sample points for coring were randomly selected from a permanent grid and one core was collected approximately $1 \mathrm{~m}$ from each of the 13 reference points (the number of cores needed to meet the desired level of precision). When rocks prevented sample collection at that spot, the area surrounding the point was probed with a metal pin until an appropriate coring site was located. The places where cores were removed were marked, and no cores were taken within 1 meter of a previous sample location. Samples were collected on April 5 1986, October 22 1986, April 11 1987, October 171987.

Root decomposition rates were measured using standard mesh bag techniques (Gosz et al., 1973; Joslin and Henderson, 1987; McClaugherty et al., 1984). Root material (both live and dead) was collected in April 1986 and April 1987 from soil cores, cleaned of soil and debris, sorted into the three diameter size classes $(<0.5 \mathrm{~mm}, 0.5-1.5 \mathrm{~mm}$ and $>1.5-3.0 \mathrm{~mm}$ ), and air dried. The masses of root samples were estimated by oven-drying $\left(70^{\circ} \mathrm{C}\right)$ subsamples of the air dried roots and developing a fresh mass conversion factor.
The remaining air-dried.root material was divided into 28 subsamples for each size class, and each subsample was weighed and placed in separate compartments in nylon litter decay bags of $2 \mathrm{~mm}$ mesh. Air dried masses ranged from 50 to $200 \mathrm{mg}$. On May 5, 1986 and May 7, 1987, fourteen bags were buried beneath the 0 layer and fourteen were buried at $10 \mathrm{~cm}$ depths on May 7, 1987. The decomposition litter bags installed in May 1986 were disturbed by wild animals during the late summer of 1986, rendering them useless. Of the bags buried in May 1987, seven bags of each size class from each depth were removed on October 21 1987 and on May 201988 and were transported to the lab in a cooler.

Nutrient concentrations of roots in each size class were measured using roots collected from four soil pits in July 1987. The pits were excavated by horizon to a depth of $40 \mathrm{~cm}$ and the roots from each depth were transported to the laboratory where they were refrigerated and processed within two days.

\section{Laboratory methods}

Sample cores were stored in darkness at $1^{\circ} \mathrm{C}$ for up to one year. Cores were sub-sampled by depth using a metal wedge $\left(5.45 \mathrm{~cm}^{2}\right.$ by $\left.3.5 \mathrm{~cm}\right)$ for each $3.5 \mathrm{~cm}$ depth interval. Roots were manually removed from the soil, washed using distilled water and, with the aid of a dissecting microscope, sorted into diameter size classes $(<0.5,0.5-1.5$ and $>1.5-3.0 \mathrm{~mm})$ and live (biomass) and dead (necromass) categories. Very fine roots $(<0.5 \mathrm{~mm})$ were considered dead when the cortex had separated from the pericycle (Persson, 1980a,b). Larger roots ( 0.5 to $3.0 \mathrm{~mm}$ in diameter) were considered alive if they were resilient, and dead when they fragmented easily and were gray to black in color (McClaugherty et al., 1982).

Because differences in root density can disproportionately influence the uptake of different nutrients (Bowen, 1984), root density was determined by measuring the length of roots in soil core samples. Density was estimated as root length per unit soil volume, a preferred measurement for calculating water and nutrient uptake (Böhm, 1979). Live root lengths were measured using an image analyzer (Decagon Devices, Incorporated, Delta-T area meter) interfaced with a microcomputer. Software was used that had been produced to eliminate bias from root orientation and resolution effects that were inherent in the image analyzer (Burke and LeBlanc, 1988). The software provided accuracy and precision that exceeds other published methods 
using that analyzer for root length measurement. In addition, because the area meter only measured a limited surface area, the length accumulation feature of the software allowed measurement of entire samples. After root lengths were measured, live and dead root samples were dried at $70^{\circ} \mathrm{C}$ to a constant mass cooled in a desiccator, and weighed.

Material from the decomposition litter bags was removed and cleaned under a dissecting scope to separate the decomposing root material from soil and new root material. Samples were then oven-dried $\left(70^{\circ} \mathrm{C}\right)$ and weighed. Decomposition rates for the summer and for the year were determined for each size class of roots by subtracting the post-burial mass from the original mass estimates for each litter bag.

Roots collected for nutrient analyses were washed in distilled water shortly after collection, sorted into biomass and necromass categories and size classes (< $0.5 \mathrm{~mm}$, OS-1.5 mm, >1.5-3.0 mm), dried in a forcedair oven at $70^{\circ} \mathrm{C}$, and ground in a Wiley mill using a $20(0.85 \mathrm{~mm})$-mesh screen. Cation and phosphorus concentrations were measured using the methods of Bickelhaupt et al. (1983). Sulfur was analyzed using the methods of David et al. (1989). Dry ashing was used in the destruction of organic matter. Nitrogen was measured using the Kjeldahl method; phosphorus was determined colorimetrically using an acidified solution containing vandate and molybdate. Calcium, magnesium and potassium were determined using atomic absorption spectroscopy. Sulfur concentrations were measured using a Leco SC132 analyzer. All masses and nutrient contents were expressed on an ash-free basis.

\section{Calculations}

The tracings of root extension were converted to root length increments using the grid intercept method. The number of times a root tracing intercepted lines on a $1-\mathrm{cm}$ grid was counted at $10 \mathrm{~cm}$ depth intervals for each of the six rhizotrons. Root length was considered the product of $11 / 14 \mathrm{x}$ the number tallied (Tennant, 1975).

The biomass estimates of live and dead fine roots were corrected for ash content and coarse fragment volumes for each depth interval. Estimates of annual decomposition were calculated by multiplying the mean per cent loss rate for each root size class by mean necromass. No attempt was made to measure the rapid decomposition rate characteristic of the initial two months (Joslin and Henderson 1987; McClaugherty et al., 1984).

Fine root production was estimated using three methods. The first method calculated production as the differences in biomass between the seasonal maximum and minimum in the top 14-cm of soil and in the 14-28 cm soil depth, a modification of methods used by Aber et al. (1985), Edwards and Harris (1977), and McClaugherty et al. (1982).

The second method employed ' $t$ ' tests calculated on biomass and necromass to estimate fine root production in a slightly different way, according to Vogt et al. (1986a) and Vogt and Persson (1990). This modification of other approaches (Harris et al., 1977; 1979; Joslin and Henderson, 1987; McClaugherty et al. 1982; Santantonio et al., 1977) calculated net fine root production (NPPr) as where

$$
\mathrm{NPPr}=\Delta \mathrm{B}_{\mathrm{t} 2-\mathrm{tl}}+\Delta \mathrm{M}_{\mathrm{t} 2-\mathrm{t} 1}+\mathrm{D}_{\mathrm{t} 2-\mathrm{t} 1}
$$

$$
\begin{aligned}
& \mathrm{Nppr}= \text { net primary production of } \\
& \text { roots } \\
& \mathrm{AB}= \begin{array}{c}
\text { statistically significant incre- } \\
\text { ment of biomass between the } \\
\text { sampling dates }
\end{array} \\
& \mathrm{AM}= \begin{array}{c}
\text { statistically significant incre- } \\
\text { ment in necromass between }
\end{array} \\
& \text { the sampling dates }
\end{aligned}
$$

When there was no significant change, in live root biomass, $\mathrm{AB}$ was zero and significant changes in dead root mass and decomposition were used to estimate production. In order to express production on an annual basis, the mean of the two summer production estimates was added to the winter estimate. Production estimates did not include losses due to root grazing, sloughing, and exudation between sampling times because these processes are probably insignificant compared to the large error term inherent in the estimates of net production (Vogt and Persson, 1990).

The third method of estimating fine root production employed the relationship between net fine root production and aboveground litterfall (Nadelhoffer and Raich, 1992) in which $\mathrm{y}=5.52+0.76 \mathrm{x}$ where $\mathrm{y}$ is the net fine root production in carbon in $\mathrm{g} \mathrm{m}^{-2} \mathrm{yr}^{-1}$. Aboveground litter production for the site was $370 \mathrm{~g}$ $\mathrm{m}^{-2} \mathrm{yr}^{-1}$ (Johnson and Lindberg, 1992) and carbon was 0.48 the organic matter.

Mortality was also calculated two ways. The first method, similar to that described above, used differences in the seasonal maximum and minimum necro- 
mass values, with the average of the summer values added to the winter value to generate an annual estimate. The second method employed the phenologybased method and calculated mortality as the statistically significant increment of dead root mass plus dead root decomposition between each sampling date. Fine root turnover was calculated for each root size class as production/mean fine root biomass.

Nutrient fluxes with fine roots were calculated assuming that there was no translocation of nutrients during root senescence (Nambiar, 1987). Fluxes were calculated using production (ash-free dry biomass) and nutrient concentration estimates for each size class and soil depth.

Means, standard deviations and standard errors were calculated using the Standard Procedure and Statement and mean and STD options of SAS Statistics, and ' $t$ '-tests were performed using the GLM procedure, means statement and $t$ option of SAS (SAS Institute, Inc., 1985a,b).

\section{Results}

\section{Vegetation growth phenology}

Fine root elongation was quite different between years, with root length extension during 1986 more than twice that in 1987 (Fig. 1). Nevertheless, it was the timing and relative rate of root elongation and not the amount of elongation that was our concern in this study. The phenology of root elongation was similar each year: initiation occurred in mid-April in the top $10-\mathrm{cm}$, but was later in the deeper horizons. Elongation peaked during July and August in the top 40-cm, but there were no distinct peaks at the $40-50 \mathrm{~cm}$ depth. At all depths, elongation declined during September, reached minimal levels in October, and virtually ceased during the winter and early spring months.

Canopy development began in the second week of April during both years, leaves were half-expanded on May 111986 and May 16 1987, the canopy was full by May 21 and May 26, leaves started to turn by August 31 and August 22, half the leaves had turned by September 13 and September 23, and leaves had fallen by October 11 and October 12. The initiation of root elongation coincided with the initiation of bud swell, and the cessation of root growth coincided with leaffall. Assuming that root elongation indicated the accumulation of fine root biomass, production was unimodal and biomass should have peaked in the autumn.
Winter soil temperatures were about $1^{\circ} \mathrm{C}$ at 10 $\mathrm{cm}$ soil depths and $3^{\circ} \mathrm{C}$ at $50 \mathrm{~cm}$ depths, but after snowmelt soil temperatures dropped to 0.5 and $1.5^{\circ} \mathrm{C}$ at those depths (Fig. 2). At $10 \mathrm{~cm}$ soil depths, temperatures increased during April, peaked in July, declined in September, decreased rapidly to below $5^{\circ} \mathrm{C}$ during October, then declined at a slower rate during the winter months. Oscillations in soil temperature at the 50 $\mathrm{cm}$ depth were smaller than at the surface and both seasonal warming and cooling at the $50 \mathrm{~cm}$ depth lagged behind temperature changes at the $10 \mathrm{~cm}$ depth.

Rhizotrons had little effect on soil temperature. Temperatures in control sites and in the soil behind the glass faces were identical at all times at a depth of $50 \mathrm{~cm}$. At $10 \mathrm{~cm}$, temperatures were similar in test and control sites except during April 1986 and May 1987 when temperatures in the control sites were $2^{\circ} \mathrm{C}$ warmer. Soil moisture remained high during the summer of 1986 , with soil moisture always $>-15 \mathrm{kPa}$. During 1987 mean soil moisture tension ranged from -26 to $-19 \mathrm{kPa}$ during August and September.

\section{Biomass and necromass}

We expected that fine root biomass would be greater in the fall than spring, and that necromass would be greater in the spring than fall, but this relationship was observed only in 1987. During 1986, the converse was true (Table 1).

Fine root mass was greatest at the surface, with half the biomass in the top $10-\mathrm{cm}$ of soil, $90 \%$ in the top 20 $\mathrm{cm}$, and only $10 \%$ in the lower eight $\mathrm{cm}$. Similarly, the upper horizons contained the greatest rooting density with more than half $(53 \%)$ of the total root length in the top $10-\mathrm{cm}$ of soil. Rooting intensity was $0.9 \mathrm{~cm}$ $\mathrm{cm}^{-3}$ in the top-3.5 $\mathrm{cm}$ of soil, was $0.3-0.4 \mathrm{~cm} \mathrm{~cm}^{-3}$ to a depth of $18 \mathrm{~cm}$ and was about $0.1 \mathrm{~cm} \mathrm{~cm}$ cm$^{-3}$ below $18 \mathrm{~cm}$. Roots $<0.5 \mathrm{~mm}$ in diameter accounted for $92 \%$ of the total length of the fine root standing crop.

Fine root dynamics

Fine root production estimates differed with the method used for calculation. Production was $2.3 \mathrm{t}$ $\mathrm{ha}^{-1} \mathrm{yr}^{-1}$ with the maximum minus minimum method, $2.0 \mathrm{t} \mathrm{ha}^{1} \mathrm{yr}^{-1}$ with the phenology-based method and $2.9 \mathrm{t} \mathrm{ha}^{-1} \mathrm{yr}^{-1}$ with the litterfall method. Production estimates obtained using the phenology-based method were heavily influenced by the mortality and decomposition estimates because there were few significant 

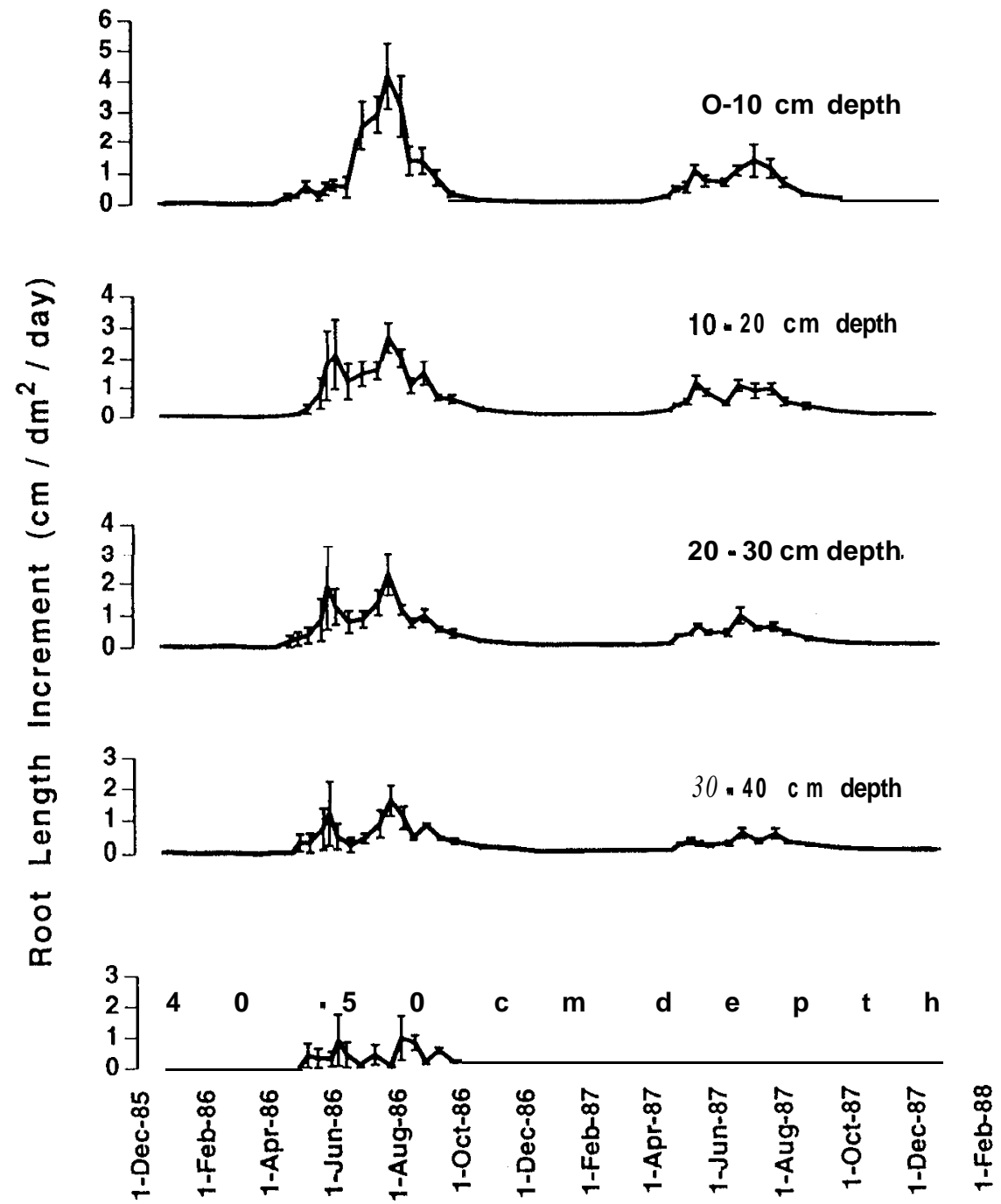

Fig. 1. Fine root growth periodicity in soil profiles determined using rhizotrons at Huntington Forest, New York, USA (mean and 95\% confidence interval, $\mathrm{n}=6$ ).

increments in biomass between sampling dates (Table 1).

Estimates of fine root mortality also differed with the method of calculation. The maximum minus minimum method estimated mortality at $3.7 \mathrm{t} \mathrm{ha}^{-1} \mathrm{yr}^{-1}$ and mortality was $1.8 \mathrm{t}$ ha-' $\mathrm{yr}^{-1}$ with the phenology method.

Decomposition was $0.9 \mathrm{t} \mathrm{ha}^{-1} \mathrm{yr}^{-1}$, or 24 to $50 \%$ of mortality. After one year, substantially more mass was lost from decomposition litter bags buried at 10 $\mathrm{cm}$ than from bags placed under the litter (Table 2). Very fine roots decomposed most rapidly and intermediate sized roots decomposed most slowly. There was no decomposition in the intermediate size root class between the $5^{\text {th }}$ and $12^{\text {th }}$ months.

\section{Nutrient flux via fine roots}

Nutrient concentrations of fine roots, adjusted for ashfree dry mass, are given in Table 3 . Ca and K concentrations increased with increasing root diameter Size class, and $\mathrm{N}$ concentrations decreased with increasing diameter size class. Also, $\mathrm{N}$ concentrations declined with increasing soil depth. $\mathrm{Mg}, \mathrm{P}$, and S concentrations did not vary with root diameter size or soil depth.

Estimates of the annual fluxes of nutrients with fine roots are given in Table 4. In general, fine roots were 
Table I. Fine root biomass and necromass $\left(t_{\text {ha }}{ }^{-1}\right)$ by diameter size class and depth at four dates at Huntington Forest, New York, USA (mean and standard error of the mean, $\boldsymbol{n}=13$ for the O-14 cm depth, $\mathbf{n}=11$ for the $14-28 \mathrm{~cm}$ depth)

\begin{tabular}{|c|c|c|c|c|}
\hline Diameter size class & April 51986 & October 221986 & April 111987 & October 171987 \\
\hline \multicolumn{5}{|l|}{$<0.5 \mathrm{~mm}$} \\
\hline & \multicolumn{4}{|l|}{ Biomass } \\
\hline O-14 cm depth & $1.470 \quad(0.184)$ & $0.866(0.108)$ & $0.540(0.089)$ & $1.044(0.176)^{\mathfrak{a}}$ \\
\hline \multirow[t]{2}{*}{$14-28 \mathrm{~cm}$ depth } & $0.278(0.127)$ & $0.204(0.035)$ & $0.185(0.073)$ & $0.707(0.608)$ \\
\hline & \multicolumn{4}{|l|}{ Necromass } \\
\hline O-14 cm depth & $0.497(0.119)$ & $0.892(0.105)^{\mathrm{a}}$ & $1.027 \quad(0.110)$ & $1.037 \quad(0.091)$ \\
\hline 14-28 cm depth & $0.104(0.044)$ & $0.383(0.055) "$ & $0.497(0.122)$ & $0.254(0.062)$ \\
\hline \multicolumn{5}{|l|}{$0.5-1.5 \mathrm{~mm}$} \\
\hline & \multicolumn{4}{|l|}{ Biomass } \\
\hline O-14 cm depth & $0.665(0.068)$ & $0.374(0.045)$ & $0.261 \quad(0.050)$ & $0.369(0.048)$ \\
\hline \multirow[t]{2}{*}{$14-28 \mathrm{~cm}$ depth } & $0.320(0.093)$ & $0.124(0.018)$ & $0.074(0.036)$ & $0.122(0.041)$ \\
\hline & \multicolumn{4}{|l|}{ Necromass } \\
\hline O-14 cm depth & $0.326(0.055)$ & $0.642(0.065)^{\mathrm{a}}$ & $0.738(0.087)$ & $0.944(0.095)$ \\
\hline 14-28 cm depth & $0.110(0.042)$ & $0.483(0.058)^{\mathrm{a}}$ & $0.607(0.056)$ & $0.347(0.058)$ \\
\hline \multicolumn{5}{|l|}{$>1.5-3.0 \mathrm{~mm}$} \\
\hline & \multicolumn{4}{|l|}{ Biomass } \\
\hline O-14 cm depth & $0.626(0.140)$ & $0.214(0.057)$ & $0.228(0.123)$ & $0.417(0.225)$ \\
\hline \multirow[t]{2}{*}{$14-28 \mathrm{~cm}$ depth } & $0.269(0.177)$ & $0.056(0.023)$ & $0.065(0.003)$ & $0.468(0.016)^{\mathrm{a}}$ \\
\hline & \multicolumn{4}{|l|}{ Necromass } \\
\hline O-14 $\mathrm{cm}$ depth & $0.070(0.032)$ & $0.227(0.057)^{\mathrm{a}}$ & $0.964(0.286)^{\mathrm{a}}$ & $0.329(0.110)$ \\
\hline $14-28 \mathrm{~cm}$ depth & $0.016(0.022)$ & $0.178(0.046)^{\mathrm{a}}$ & $0.830(0.320) "$ & $0.195(0.088)$ \\
\hline
\end{tabular}

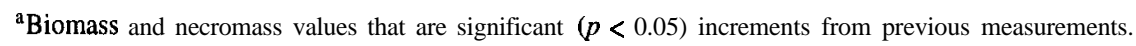

not as important as foliage in the cycling of nutrients at Huntington Forest, but the relative contribution to elemental cycles depended on the method used to measure fine root production.

\section{Discussion}

\section{Periodicity of growth}

The strongly unimodal pattern of root elongation with a mid-summer peak in this study is similar to reports for European birch by Ovington and Murray (1968) but contrasts with other reports for northern hardwood forests in the United States. However, these reports of spring peaks in fine root production were based on the number of non-mycorrhizal roots (Harley, 1937), the proportion of white root tips (Morrow, 1950), and root extension into root free soil cores (e.g., McClaugherty
Table 2. Percent root mass lost from decomposition hitter bags between May and November 1987 (5 months) and between May 1987 and April 1988 (1 year) at Huntington Forest, New York, USA (means and standard errors, $\mathbf{n}=\mathbf{5}$ to 9 )

\begin{tabular}{llll}
\hline & $\begin{array}{l}\text { Root dia- } \\
\text { meter }(\mathrm{mm})\end{array}$ & 5 months & 1 year \\
\hline Litter layer & & $13.9(2.2)$ & $30.0(5.3)$ \\
& $<0.5$ & $20.4(4.6)$ & $17.4(3.7)$ \\
& $0.5-1.5$ & $10.9(2.3)$ & $20.9(3.2)$ \\
& $>1.5-3.0$ & & \\
10 cm depth & & $9.3(3.4)$ & $52.1(7.3)$ \\
& $<0.5$ & $28.5(6.4)$ & $27.2(5.5)$ \\
& $0.5-1.5$ & $16.3(3.6)$ & $34.9(7.8)$ \\
& $>1.5-3.0$ & &
\end{tabular}




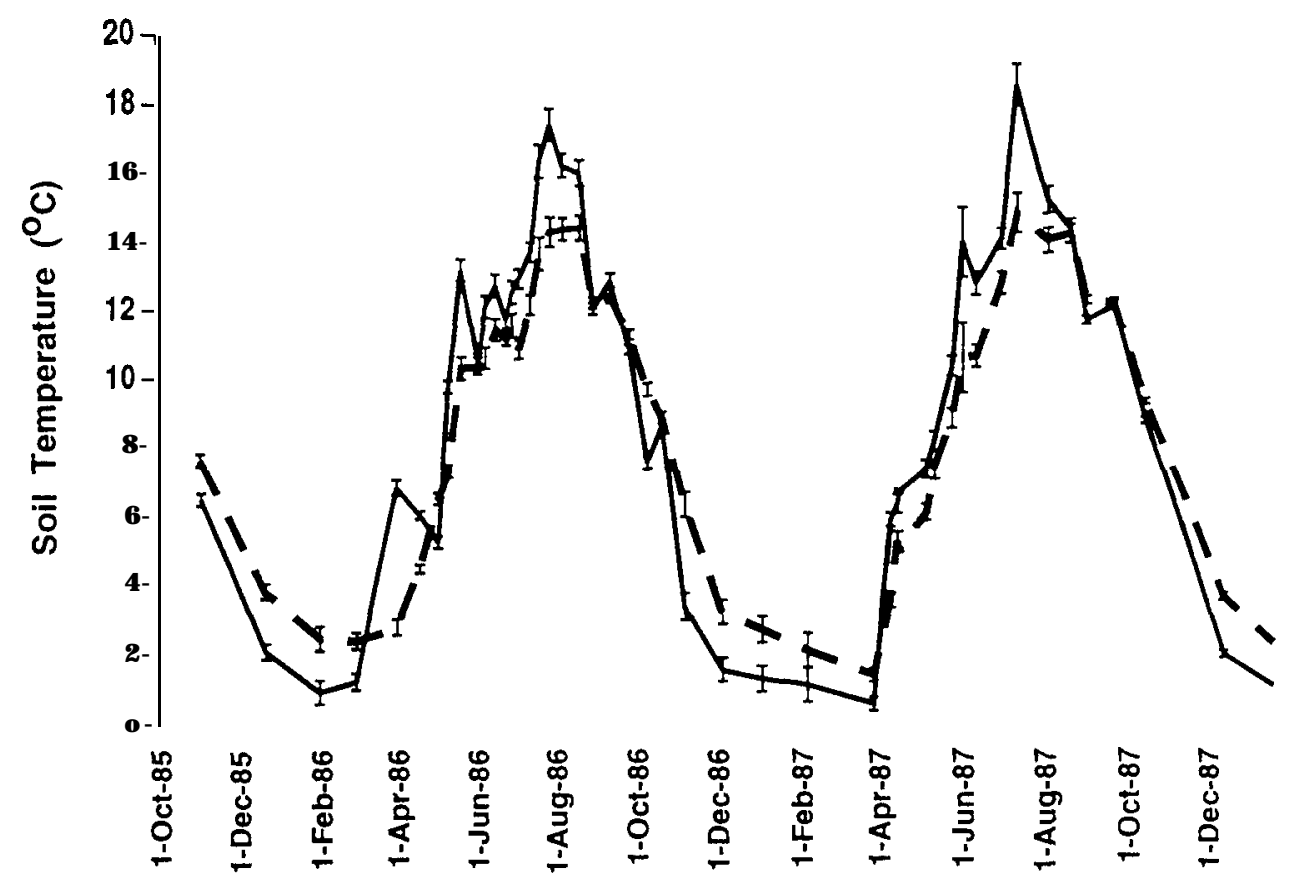

Fig. 2. Comparison of temperatures at $10 \mathrm{~cm} \mathrm{(-)} \mathrm{and} 50 \mathrm{~cm} \mathrm{(-)}$ soil depths in rhizotrons at Huntington Forest, New York, USA (mean and $95 \%$ confidence interval, $\mathrm{n}=6$ ).

et al., 1982), and these methods may be biased toward spring signals. In fact, McClaugherty et al. reported that autumn was the time of maximum fine root biomass even though he found that growth into soil cores peaked in April and May.

In this cool and moist forest, fine root elongation phenology was clearly controlled by soil warming and cooling. The initiation and cessation of growth coincided with soils reaching temperatures of $5^{\circ} \mathrm{C}$, a minimum temperature for root growth (Webb, 1976) even though seed germination and seedling radicle growth in sugar maple occurred below this temperature (Dustin and Raynal, 1986; Rutman, 1983). In addition, root elongation was correlated with soil temperature in the top $10-\mathrm{cm}$ of soil $(\mathrm{r}=0.871, \mathrm{n}=21, p<0.01)$. Although soil moisture did not appear to influence growth phenology during this study, mid-summer droughts caused bimodal root growth patterns in other deciduous forests (Kuhns et al., 1985; Teskey and Hinkley, 1981). Except during unusually dry years at Huntington Forest, the peaks of fine root growth and temperature should coincide, and, as in 1986 and 1987, a mid-summer peak in elongation should result in an autumn maximum in fine root biomass.

Although the quantity of root elongation differed between 1986 and 1987, this was not important in our study because the phenology of root elongation was identical. Therefore data from both years were useful in approximating the biomass maxima and minima. In fact, we had expected the newly constructed rhizotrons to stimulate root elongation during 1986, because this occurred the first year after rhizotron construction in another study (Ovington and Murray, 1968). The possible injury induced or nutrient stimulated root growth did not affect the value of these data, which were used only for determining the timing of fine root growth.

The synchronous initiation of root growth with bud swell was similar to the findings in studies of birch (Ovington and Murray, 1968) and white oak forests (Teskey and Hinkley, 1981), and is consistent with observations of Richardson (1958) who suggested that a hormonal stimulus associated with bud swell is required for the initiation of root growth.

\section{Biomass and necromass}

The mass of fine roots in this study (5.4 t ha-") was substantially lower than estimates from some $(9.1 \mathrm{t}$ ha $^{-1}$, McClaugherty et al., 1982 and 12.5 t ha-', Safford, 1974), but not all temperate deciduous forests (5.1 t ha ${ }^{-1}$ Harris et al., 1977, $6.7 \mathrm{t}^{\text {ha- }}{ }^{-}$, Joslin and Henderson, 1987). A possible explanation for these 
Table 3. Nutrient concentrations of fine root by diameter size class and horizon at Huntington Forest, New York, USA Values are expressed as per cent by weight (mean \pm standard error of the mean, expressed as per cent by weight)

\begin{tabular}{llcccccc}
\hline Root size & Horizon & $\mathrm{Ca}$ & $\mathrm{Mg}$ & $\mathrm{K}$ & $\mathrm{P}$ & $\mathrm{N}$ & $\mathrm{S}$ \\
\hline$<0.5$ & $\mathrm{O} / \mathrm{a}$ & $0.2(0.04)$ & $0.07(0.00)$ & $0.10(0.00)$ & $0.08(0.01)$ & $1.66(0.07)$ & $0.15(0.01)$ \\
& $\mathrm{E}$ & $0.18(0.02)$ & $0.08(0.08)$ & $0.13(0.02)$ & $0.08(0.00)$ & $1.49(0.04)$ & $0.14(0.01)$ \\
& $\mathrm{B}_{\mathrm{h}}$ & $0.16(0.01)$ & $0.07(0.06)$ & $0.08(0.01)$ & $0.09(0.00)$ & $1.41(0.05)$ & $0.13(0.00)$ \\
& $\mathrm{B}_{\mathrm{hs}}$ & $0.15(0.02)$ & $0.08(0.01)$ & $0.09(0.01)$ & $0.08(0.00)$ & $1.19(0.04)$ & $0.11(0.01)$ \\
& $20-40 \mathrm{~cm}$ & $0.23(0.08)$ & $0.1(0.02)$ & $0.13(0.03)$ & $0.08(0.00)$ & $1.08(0.04)$ & $0.11(0.00)$ \\
& & & & & & & \\
$0.5-1.5$ & $\mathrm{O} / \mathrm{a}$ & $0.39(0.03)$ & $0.08(0.02)$ & $0.17(0.03)$ & $0.07(0.01)$ & $1.21(0.07)$ & $0.11(0.01)$ \\
& $\mathrm{E}$ & $0.30(0.02)$ & $0.07(0.01)$ & $0.16(0.02)$ & $0.06(0.00)$ & $0.98(0.06)$ & $0.10(0.01)$ \\
& $\mathrm{B}_{\mathrm{h}}$ & $0.31(0.03)$ & $0.07(0.00)$ & $0.15(0.01)$ & $0.06(0.01)$ & $0.91(0.04)$ & $0.09(0.00)$ \\
& $\mathrm{B}_{\mathrm{hs}}$ & $0.32(0.01)$ & $0.09(0.01)$ & $0.13(0.01)$ & $0.06(0.00)$ & $0.88(0.83)$ & $0.09(0.00)$ \\
& $20-40 \mathrm{~cm}$ & $0.36(0.08)$ & $0.09(0.01)$ & $0.14(0.02)$ & $0.06(0.00)$ & $0.87(0.02)$ & $0.09(0.00)$ \\
& & & & & & & \\
$>1.5-3.0$ & $\mathrm{O} / \mathrm{a}$ & $0.52(0.05)$ & $0.08(0.08)$ & $0.19(0.03)$ & $0.06(0.01)$ & $0.93(0.05)$ & $0.09(0.01)$ \\
& $\mathrm{E}$ & $0.49(0.03)$ & $0.07(0.01)$ & $0.20(0.03)$ & $0.06(0.01)$ & $0.86(0.02)$ & $0.07(0.00)$ \\
& $\mathrm{B}_{\mathrm{h}}$ & $0.41(0.02)$ & $0.08(0.00)$ & $0.21(0.2)$ & $0.06(0.01)$ & $0.81(0.05)$ & $0.07(0.01)$ \\
& $\mathrm{B}_{\mathrm{hs}}$ & $0.65(0.04)$ & $0.09(0.01)$ & $0.20(0.02)$ & $0.06(0.00)$ & $0.81(0.03)$ & $0.08(0.00)$ \\
& $20-40 \mathrm{~cm}$ & $0.66(0.34)$ & $0.08(0.02)$ & $0.12(0.03)$ & $0.06(0.00)$ & $0.81(0.06)$ & $0.07(0.01)$ \\
\hline
\end{tabular}

differences is that rock fragments comprised a large portion of the soil volume at Huntington Forest: $5 \%$ at the surface, about $20 \%$ to a soil depth of $20 \mathrm{~cm}$ and $40 \%$ at soil depths below $20 \mathrm{~cm}$. In contrast, rock fragments comprised only $9 \%$ of the soil volume in the forest studied by McClaugherty et al. (1982) and Safford did not report rock fragments.

Decomposition rates of fine roots in this study were similar to those reported for other deciduous forests (about 25\% $\mathrm{yr}^{-1}$, Joslin and Henderson, 1987; McClaugherty et al., 1982). Although we did not measure the initial rate of decomposition, the inclusion of live roots may have resulted in higher decomposition rates than if only dead roots were used. In illustration, McClaugherty et al. (1984) included live roots in their root decomposition study and documented a large initial loss of mass. As in this study, McClaugherty et al. (1982) reported greater rates of decomposition in mineral soil compared to the forest floor. However, Fahey et al. (1988) reported slower rates of decay in the mineral soil. Our results are consistent with some findings that fine roots decay more rapidly than large roots (Fahey et al., 1988; Joslin and Henderson, 1987) but differ from McClaugherty et al. (1984) results which showed very fine roots decayed more slowly than larger fine roots. Undoubtedly, microsite and climatic conditions as well as species-specific structural composition contribute to differences in decomposition rates among studies. It is unclear why in this study the intermediate size roots did not decompose between 5 and 12 months, but other studies also reported no change or even an increase in mass after five months (e. g. McClaugherty et al., 1982; Figure 4).

Fine root dynamics

Similar estimates for biomass and necromass during both years of this study and similar production and mortality estimates $(14 \%$ difference with the phenology-based method) suggest that fine root dynamics at Huntington Forest are in a steady state. However, production and mortality were quite different $(60 \%)$ when the maximum minus minimum method was used. McClaugherty et al. (1982) also reported similar production and mortality estimates and similar biomass and necromass, suggesting that forest was also in steady state. In contrast, a study of white oak forests revealed root biomass was greater than necromass but production, mortality and decomposition were similar (Joslin and Henderson, 1987). Estimates of fine root turnover ranged from 0.7 to $2.0 \mathrm{yr}^{-1}$, values similar to 
that for fine roots in a mixed deciduous forest $\left(0.7 \mathrm{yr}^{-1}\right.$ McClaugherty et al., 1982) and in a Belgian beech forest (0.6 yr $^{-1}$, Van Praag et al., 1988); a substantially smaller turnover was reported for a white oak forest (0.2 $\mathrm{yr}^{-1}$, Joslin and Henderson, 1987).

\section{Comparison of methods}

The three methods generated quite similar production estimates ( $\pm 20 \%$ of the three estimate means), however, mortality estimates were quite different between methods (200\%). Each method used to estimate these processes has advantages and disadvantages. The maximum minus minimum method as used here has a potential for overestimating production and mortality by incorporating random error into the estimates. Nevertheless, there are ways to limit inclusion of this error: this method should be limited to ecosystems where production is unimodal, sampling should be limited to twice a year, and the time of sample collection should be dictated by a phenological indicator of production other than standing crop. In addition, only significant differences should be included in the calculations. More than one year of data will also help reduce the potential for overestimation. If only significant differences (both positive and negative) were included in these, calculations, production would have been $1.5 \mathrm{t} \mathrm{ha}^{-1} \mathrm{yr}^{-1}$ and mortality $0.8 \mathrm{t} \mathrm{ha}^{-1} \mathrm{yr}^{-1}$.

Potential sources of error in the phenology-based method involve the use of decomposition in estimates of production and mortality. There are innate problems associated with the standard method of measuring decomposition (litter bags) that include restriction of meso-and macrofauna from the litterbag contents, potential loss of fine root laterals from the bags, and a potential for using non-representative root samples in the litterbags, such as when only one age class of root is used. In addition, any inaccuracy in necromass estimates would magnify error in the estimate of decomposition. In this study, the use of only one year of decomposition litter bag data representing a single age class of roots may have added error. Nevertheless, production estimates were quite similar to those generated using the other two methods, suggesting that decomposition estimates did not contain a significant amount of error.

The litterfall method cannot be used to test the accuracy of the other methods because the equation used litterfall values and N-budget. generated root production estimates from other forested systems. Even in that study, root production estimates were only sometimes similar to those obtained when the maximum minus minimum method was used (Nadelhoffer and Raich, 1992).

Clearly, fine roots are important contributors to the detrital pool at Huntington Forest. Depending on the method used to estimate mortality, production of fine root detritus was between $33 \%$ and $50 \%$ of the total detritus production in this forest (based on $3.7 \mathrm{tha}^{-1}$ $\mathrm{yr}^{-1}$ for aboveground litter production at Huntington Forest, Johnson and Lindberg, 1992). These proportions are at the low to middle range of estimates for temperate deciduous forests (Cox et al., 1977, 1978; Harris et al., 1979; Joslin and Henderson, 1987; McClaugherty et al., 1982; Nadelhoffer et al., 1985).

\section{Role of fine root dynamics in nutrient budgets}

The concentrations of $\mathrm{N}, \mathrm{P}, \mathrm{K}, \mathrm{Ca}$ and $\mathrm{Mg}$ in fine roots were within the range reported for other forests (Fahey et al., 1988; Joslin and Henderson, 1987; McClaugherty et al., 1982; Van Praag et al., 1988), but S concentrations were substantially lower than those from a Belgian beech forest (Van Praag et al., 1988). Decreasing $\mathrm{N}$ concentrations with increasing root diameter was also reported by Fahey et al. (1988) in American beech but not in sugar maple and yellow birch, as was documented in this study. $K$ concentrations increased with root size in this study, but the reverse pattern was shown for another northern hardwood forest (Fahey et al., 1988) and a white oak forest (Joslin and Henderson, 1987).

In general, fine roots were not as important as foliage in the cycling of nutrients at Huntington Forest. Regardless of the method used to estimate production, fine roots were less important than foliage in the cycling of $\mathrm{Ca}$ and $\mathrm{Mg}$, and were almost as important as foliage in the cycling of K, N, P and S (Table 4). This contrasts with two other temperate deciduous forests: fine root turnover was as important as leaves in the cycling of $\mathrm{Ca}, \mathrm{N}$ and $\mathrm{P}$, and were more important than foliage in the cycling of $\mathrm{Mg}$ and $\mathrm{K}$ in a white oak stand (Joslin and Henderson 1987) and fine roots were distinctly more important than leaves in the cycling of all elements in a Belgian beech forest (Van Praag et al., 1988). Thus, the role of fine roots in nutrient cycling can vary widely among forests, and it may take direct measurement of the fine root dynamics to obtain accurate nutrient budgets in forested ecosystems. 
Table 4. Annual organic matter production and the nutrient fluxes via roots (and via fine roots as a fraction of the production and nutrient flux with litterfall) at Huntington Forest, New York, USA

\begin{tabular}{|c|c|c|c|c|c|c|c|}
\hline & $\mathrm{OM}$ & $\mathrm{Ca}$ & $\mathrm{Mg}$ & $\mathrm{K}$ & $\mathrm{P}$ & $\mathrm{N}$ & $s$ \\
\hline \multicolumn{8}{|c|}{$\left(\mathrm{kg} \mathrm{ha}^{-1} \mathrm{yr}^{-1}\right)$} \\
\hline North. Hardwood ${ }^{a}$ & $2,004(0.55)$ & $4.5(0.12)$ & $1.1 \quad(0.22)$ & $0.3(0.45)$ & $1.2(0.40)$ & $20.3(0.36)$ & $1.8 \quad(0.33)$ \\
\hline North. Hardwood ${ }^{b}$ & $2,312(0.62)$ & $5.22(0.12)$ & $1.3 \quad(0.22)$ & $0.3(0.40)$ & $1.4(0.35)$ & $23.4(0.33)$ & $2.0(0.30)$ \\
\hline North. Hardwood ${ }^{\mathrm{c}}$ & $2,700(0.73)$ & $6.1(0.14)$ & $1.4 \quad(0.24)$ & $0.4(0.50)$ & $1.7(0.44)$ & $27.3(0.39)$ & $2.4(0.38)$ \\
\hline White oak ${ }^{\mathrm{d}}$ & $1,060 \quad(0.32)$ & $10.3 \quad(0.24)$ & $2.0(0.54)$ & $4.1(0.50)$ & $0.7(0.28)$ & $14.6 \quad(0.34)$ & nd \\
\hline White oak ${ }^{\mathrm{e}}$ & $2,200(0.66)$ & $22.3(0.52)$ & $3.6 \quad(0.97)$ & $7.5(0.91)$ & $1.4(0.56)$ & $22.4(0.52)$ & nd \\
\hline European beech' & 4,393 (1.29) & $62.0(3.68)$ & $7.1 \quad(1.30)$ & $2.2(1.23)$ & $3.6(1.56)$ & $58.4(1.50)$ & $5.7(0.84)$ \\
\hline Mixed oak forests & $6,004(1.40)$ & $27.6(0.81)$ & $10.2 \quad(1.67)$ & $9.7(1.51)$ & $3.0(0.86)$ & $42.0(1.78)$ & nd \\
\hline
\end{tabular}

${ }^{a b c}$ This study. Litter production and nutrient contents from Johnson and Lindberg (1992).

${ }^{a}$ Fine root production estimates obtained using the phenology-based method.

${ }^{b}$ Fine root production estimates obtained using the maximum minus minimum method.

${ }^{c}$ Fine root production estimates using the litterfall method.

${ }^{\mathrm{d}}$ Roots $<2 \mathrm{~mm}$ in diameter for a forest in Missouri, USA, from Joslin and Henderson, 1987.

${ }^{\mathrm{e}}$ Roots $\leqslant 5 \mathrm{~mm}$ in diameter for a forest in Missouri, USA, from Joslin and Henderson, 1987.

${ }^{f}$ Data for roots $\leqslant 5 \mathrm{~mm}$ in diameter for a forest in the Belgian Ardennes, from Van Praag et al., 1988

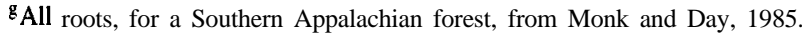

\section{Acknowledgements}

This research was part of the Integrated Forest Study (RP2621-2) sponsored by the Electric Power Research Institute, the Empire State Electric Energy Research Corporation and the New York State Energy Research and Development Authority. We appreciate the helpful discussions with Charles A McClaugherty, Kristiina Vogt, Gray S Henderson, J Devereux Joslin, Hans Persson, and Myron Mitchell, the field and lab assistance of Steve Schindler, Tommy Scott, Diedre Aldcorn, Karin Readel, Jeremy Buck, Vassiliki Nickolaros, Joanna Smith, Bettina Descisciolo, Ronald Leonard, Yude Pan, Michele Delahunt, Laurie Jeffers, Caryn Crook, Dana D'Agostino, Marie Root, Matthew Werner, Scott Rosecranz, Rich Corcoran, Ming-Chung Lin, and Nancy Mathews, and the statistical help of David LeBlanc, Brian Fitzgerald, David Gardner and graphical help of Cindy Bunton. We thank Kristiina Vogt, J Devereux Joslin and two anonymous reviewers for their helpful suggestions on an earlier manuscript.

\section{References}

Aber J D, Melillo J M, Nadelhoffer K J, McClaugherty C A and Pastor J 1985 Fine root turnover in forest ecosystems in relation to quantity and form of nitrogen availability: a comparison of two methods. Oecologia 66.3 17-32 1 .
Aber J D, Melillo J, Nadelhoffer K J, Pastor J and Boone R D 1991 Factors controlling nitrogen cycling and nitrogen saturation in northern temperate forest ecosystems. Ecol. Appl. 1, 305-3 15.

Bickelhaupt D H, Davey C B and White E H 1983 Laboratory methods for forest tree nursery soil analysis. SUNY College of Environ. Sci. and For. Misc. Pub. No. 2 (ESF 83-004), Syracuse, NY, USA.

Böhm W 1979 Methods of studying root systems. Springer-Verlag. NY, USA $188 \mathrm{p}$.

Burke M K and LeBlanc D C 1988 Rapid measurement of fine root length using photoelectronic image analysis. Ecology 69, 12861289

Cox T L, Harris W F, Ausmus B S and Edwards N T 1977 The role of roots in biogeochemical cycles in eastern deciduous forests. In The belowground Ecosystem: a Synthesis of Plant and associated Processes. Ed. J K Marshall. pp 321-326. Range Science Department Science Series No. 26, Colorado State University, Fort Collins, CO, USA.

Cox T L, Harris W F, Ausmus B S and Edwards N T 1978 The role of roots in biogeochemical cycles in an eastern deciduous forest. Pedobio. 18, 264-271,

David M B, Mitchell M J, Aldcorn D and Harrison R B 1989 Analysis of sulfur in soil, plant and sediment materials: Sample handling and use of an automated analyzer. Soil Biol. Biochem. 21, 119123.

David MB, Mitchell M J and Scott T J 1987 Importance of biological processes in the sulfur budget of a northern hardwood ecosystem. Biol. Fen. Soils. 5, 258-264.

Dustin D C and Raynal D J 1988 Effects of simulated acid rain on sugar maple seedling root growth. Environ, Exper. Bot. 28, 207-2 13.

Edwards N T and Harris 1977 Carbon cycling in a mixed deciduous forest floor. Ecology 58, 431-437.

Fahey T J, Hughes J W, Ou M and Arthur M A 1988 Root decomposition and nutrient flux following whole-tree harvest of northern hardwood forest. For. Sci. 34, 744-768. 
Gosz J R, Likens G E and Bormann F H 1973 Nutrient release from decomposing leaf and branch litter in the Hubbard Brook Forest, New Hampshire. Ecol. Monogr. 43, 173-191.

Harley J L 1937 Ecological observations on the mycorrhiza of beech (preliminary note). J. Ecol. 25, 421-423.

Harris W F, Kinerson R S and Edwards N T 1977 Comparison of belowground biomass of natural deciduous forest and loblolly pine plantations. In The belowground Ecosystem: A Synthesis of Plant-associated Processes. Ed. J K Marshall, pp 29-38 Range Science Department Science Series No. 26. Colorado State Univ., Fort Collins, CO, USA.

Harris W F, Santantonio D and McGinty D 1979 The dynamic belowground ecosystem. In Forests: Fresh perspectives from ecosystem analysis. Ed. R H Waring, Proceedings of the 40th Ann. Biol. Colloq. 1979, Oregon State U. Press, Corvallis, OR, USA.

Hendrick R L and Pregitzer K S 1993 Patterns of fine root mortality in two sugar maple forests. Nature 361, 59-61.

Johnson D W and Lindberg S E 1992 Atmospheric deposition and forest nutrient cycling. Springer-Verlag, New York, NY, USA, $707 \mathbf{p}$.

Joslin J D and Henderson G S 1987 Organic matter and nutrients associated with fine root turnover in a white oak stand. For. Sci. 33, 330-346.

Keyes M R and Crier C C 1981 Above- and belowground net production in 40-year-old Douglas-fir stands on low and high productivity sites. Can. J. For. Res. 11, 599-605.

Kuhns M R, Garre H E, Teskey R 0 and Hinckley T M 1985 Root growth of black walnut trees related to soil temperature, soil water potential, and leaf water potential. For. Sci. 3 1, 612-629.

Kurz W A and Kimmins J P 1987 Analysis of some sources of error in methods used to determine fine root production in forest ecosystems: asimulation approach. Can. J. For. Res. 17, 909-912.

Lauenroth W K, Hunt H W, Swift D M and Singh J S 1986 Reply to Vogt et al. Ecology 67, 580-582.

McClaugherty C A, Aber J D and Melillo J M 1982 The role of fine roots in the organic matter and nitrogen budgets of two forested ecosystems. Ecology 63, 1481-1490.

McClaugherty C A, Aber J D and Melillo J M 1984 Decomposition dynamics of fine roots in forested ecosystems. Oikos 42, 378-386.

Mitchell M J, Burke M K and Shepard J P 1992 Seasonal and spatial patterns of $\mathrm{S}, \mathrm{Ca}$, and $\mathrm{N}$ dynamics of a Northern Hardwood forest ecosystem. Biogeochemistry. 17, 165-189.

Mollitor A W and Raynal D J 1982 Acid precipitation and ionic movement in Adirondack forest soils. Soil Sci. Soc. Am. J. 46, 137-141.

Monk C D and Day Jr F P 1985 Vegetation analysis, primary production and selected nutrient budgets for a southern Appalachian oak forest: a synthesis of IBP studies at Coweeta. For. Ecol. Manage. 1087-1 13.

Morrow R R 1950 Periodicity and growth of sugar maple surface layer roots. J. For. 48, 875-88 1 .

Nadelhoffer K J, Aber J D and Melillo JM 1985 Fine roots, net primary production, and soil nitrogen availability: a new hypothesis. Ecology 66, 1377-1390.

Nadelhoffer K J and Raich J W 1992 Fine root production estimates and belowground carbon allocation in forest ecosystems. Ecology 73, 1139-1 147.

Nambiar E K S 1987. Do nutrients retranslocate from fine roots? Can. J. For. Res. 17, 913-918.

Ovington J D and Murray C 1968 Seasonal periodicity of root growth of birch trees. In Methods of productivity studies in Root Systems and Rhizosphere Organisms. Proceedings of the International Symposium, USSR. August 28-Sept 12, 1968. USSR Academy of Science. pp 146-154.
Persson H 1980a Death and replacement of fine roots in a mature Scots pine stand. In Structure and Function of northern Coniferous forests - an ecosystem study. Ed. T Persson. Ecol. Bull. (Stockholm) 32, 251-260.

Persson H 1980b Spatial distribution of fine-root growth, mortality and decomposition in a young Scots pine stand in Central Sweden. Oikos 34, 77-87.

Raich J W and Nadelhoffer K J 1989 Belowground carbon allocation in forest ecosystems: global trends. Ecology 70, 13461354.

Raynal D J, Raleigh F S and Mollitor A V 1983 Characterization of atmospheric deposition and ionic input at Huntington Forest, Adirondack Mountains, New York. ESF 83-003. State University of New York, College of Environmental Science and Forestry, Institute of Environmental Program Affairs, Syracuse, NY, USA.

Richardson S D 1958 Bud dormancy and root development in Acer saccharinum. In The physiology of forest trees, Ed. K V Thimann. pp 409425. Ronald Press, NY, USA.

Rutman S 1983 Seedling Population Dynamics of Northern Hardwoods in the Adirondack Mountains, New York. M.S. Thesis. State University of New York, College of Environmental Science and Forestry, Syracuse, NY, USA.

Safford L 01974 Effect of fertilization on biomass and nutrient content of fine roots in a beech-birch-maple stand. Plant and Soil 40, 349-363.

Santantonio D, Hermann R K and Overton W S 1977 Root biomass studies in forest Ecosystems. Pedobiol. 17, 1-31,

SAS Institute, Inc 1985a SAS/GRAPH user's guide, version 5 edition, SAS Institute, Inc. Cary, NC.

SAS Institute, Inc 1985b SAS user's guide: statistics, version 5 edition. SAS Institute Inc. Cary, NC.

Singh J S, Lauenroth W K, Hunt H W and Swift D M 1984 Bias and random errors in estimators of net root production: a simulation approach. Ecology 65, 1760-1764.

Somers R C 1986 Soil Classifcation, Genesis, Morphology, and Variability of Soils found within the Central Adirondack Region of New York. Ph.D. thesis, State University of New York, College of Environmental Science and Forestry, Syracuse, NY, USA.

Tennant D 1975 A test of a modified line intersect method of estimating root length. J. Ecol. 63, 995-1001.

Teskey R 0 and Hinckley T M 1981 Influence of temperature and water potential on root growth of white oak. Physiol. Plant. 52, 363-369.

Van Praag H J, Sougnez-remy S, Weisssen F and Carletti G 1988 Root turnover in a beech and a spruce stand of the Belgian Ardennes. Plant and Soil 105, 87-103,

Vogt K A and Bloomfield J 1991. Tree root turnover and senescence. In Plant Roots. Eds Y Waisel, A Eschel and K Uzi. pp 287-306. Dekker, New York, NY, USA.

Vogt K A, Crier CC, Bower S T, Sprugel D G and Vogt D J 1986a Overestimation of net root production: a real or imaginary problem? Ecology 67, 577-579.

Vogt K A, Crier C C, and Vogt D J 1986b Production, turnover, and nutrient dynamics of above- and below-ground detritus of world forests. Adv. Ecol. Res. 15, 303-377.

Vogt K A and Persson H 1990 Measuring growth and development of roots. In Techniques and approaches in forest tree ecophysiology. Eds. J P Lassoie and T M Hinckley. CRC press, Boca Raton, FL, USA.

Webb D P 1976 Root growth in Acer saccharum March. seedlings: effects of light intensity and photoperiod on root elongation rates. Bot. Gaz. 137, 21 1-217.

Section editor: H Lambers 